\title{
Retirement literacy as a basis for prospective retirees' well-being
}

\author{
Elena Vershkova ${ }^{1}$, Tatyana Filippova ${ }^{1}$ a, Evgeniya Nekhoda ${ }^{2}$ \\ ${ }^{1}$ Tomsk Polytechnic University, 634050 Lenin Avenue, 30, Tomsk, Russia \\ ${ }^{2}$ Tomsk State University, 634050 Lenin Avenue, 36, Tomsk, Russia
}

\begin{abstract}
The article addresses the problem of teaching prospective retirees to maintain their finances, which will ensure their financial security and well-being. A key issue is the influence of financial literacy on the amount of future pension assets. The analysis of the existing instruments of pension savings enabled to suggest a complex of activities aimed at developing a prospective retirees' ability to plan and manage pension assets.
\end{abstract}

\section{Introduction}

Ensuring the retirees' adequate standard of living is an acute problem today. According to the Federal State Statistics service, as of January 1, 2015, the average established pension is 10889 roubles [1]. This pension cannot ensure retirees' secure life. Therefore, of prime importance is a mechanism to increase future pension assets. It especially refers to young working-age people who currently have an opportunity to manage pension assets. There are various financial instruments to increase future pension assets, in particular, provided by the state. The problem is that the active working-age population is unaware of these instruments or cannot use them properly, i.e. financially illiterate. Therefore, an important task of the state is to prepare prospective retirees to deal with finances, which will ensure their financial security and well-being. It implies, in particular, an ability to make decisions on pension assets management.

\section{Materials and methods}

The aim of our research is to suggest a complex of activities aimed at developing prospective retirees' ability to plan and manage pension assets.

Consequently, the aims of the research are: to outline the main components of retirement literacy and analyze their development trend, to determine the reasons impeding the development of retirement literacy skills, and pinpoint ways for increasing the level of retirement literacy of working-age people as exemplified by the Russian Federation. When studying retirement literacy of the population, a structural and functional method, comparison, analysis, synthesis, and a graph method were used.
The theoretical and methodological background to the issue discussed are fundamental works of Russian and international scientists on the urgent issues of financial literacy, as well as the works of leading experts on formation and managing pension assets.

The informational background of the research is reference and analytical materials of the Ministry of Healthcare and Social Development of the Russian Federation (RF), the RF Ministry of Finance, the RF Central Bank, official reports and press releases of the RF Pension Fund, statistical data of the RF Federal State Statistics Service, publications of the International Organization for Economic Cooperation and Development and other Russian and international organizations.

\section{Results and discussion}

Currently, the pension scheme in the Russian Federation is composed of two pillars: a pay-as-you-go pillar (PAYG) and a funded pillar. The assets needed for pension payment to the currently retired are financed by mandatory insurance contributions of workers. In other words, a working person, contributing to the funded pillar, provides some guarantee that will ensure a pension from the state at retirement. The funded pillar is indexed in accordance with the law to ensure additional income at retirement. PAYG assets management is the state responsibility, while the funded pillar is the workers' responsibility. The funded accounts are maintained either by Vnesheconombank authorized by the state, a non-state pension fund (NPF), or an externalasset management company. Every person is eligible for choosing a company which will manage his/her funded part of pension. In case a choice of asset management has not been made, worker's pension savings are passed

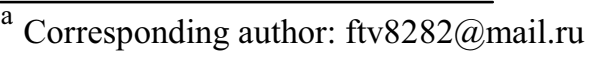


to Vnesheconombank. Choosing an asset management option of an individual funded account is one of the ways to regulate one's future pension income. It is a person's deliberate choice, which results from his/her financial literacy.

At present, there are various definitions of financial literacy in academic literature [1]. We will use G.E. Shakhnazaryan's [2] definition of financial literacy as understanding of financial matters, the ability of individuals to make appropriate decisions in managing their personal finances, as well as to make a conscious choice of financial products and services. Considering its influence upon retirement, we can point out the following aspects of financial literacy:

1) decision-making on voluntary contributions to pension assets, not relying totally on the state support;

2) finding outside sources of income to increase savings rates, apart from the funded pillar;

3) diversification of types of personal savings aimed at getting extra revenue upon retirement;

4) choosing a company to maintain funded individual accounts (a state pension fund, a non-state pension fund (NPF) or a superannuation trustee company).

As the abovementioned aspects of financial literacy refer only to individuals' pension assets, the term «retirement literacy» will be used in the article to define them. The aspects will be considered as the main components of retirement literacy.

Let us present the results of assessing the level of retirement literacy in Russia. The first component of retirement literacy is an individual's deliberate decision to make retirement savings and not to count only on support from the state. In 2015, the Public Opinion Foundation (POF) polled adults born in 1967 and later on their funded pillar. One of the questions was: «Are you going or not to save for retirement to increase the state pension upon retirement?» [4]. The results of the poll are given in figure 1 .

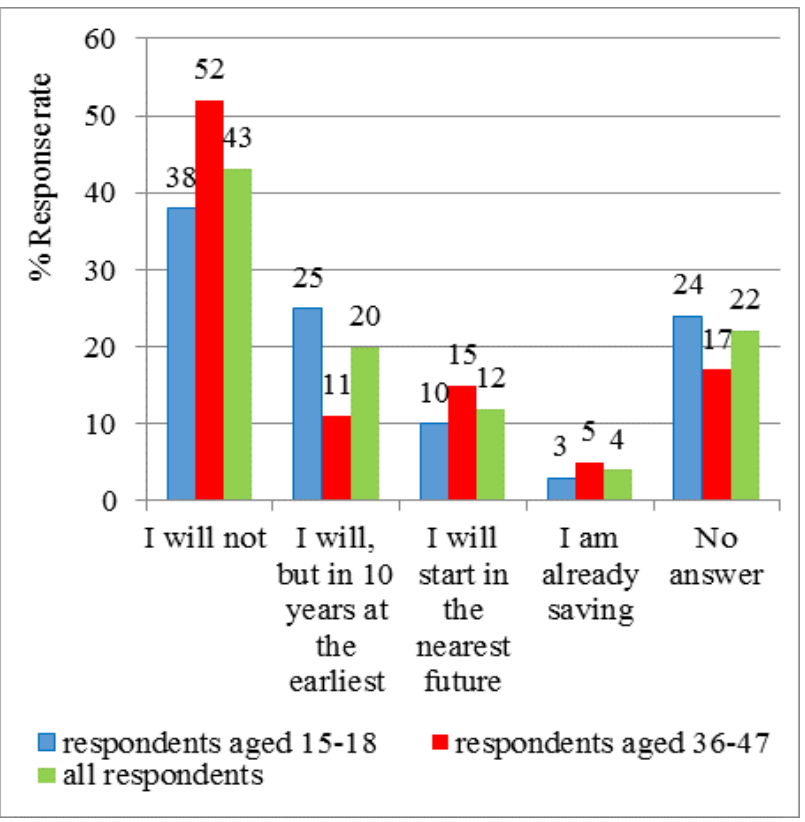

Fig. 1. Results of the poll on voluntary retirement savings (made by the authors using POF data)
As can be seen from Figure 1, most of the respondents are not planning to save for retirement. Furthermore, the respondents aged $36-47$, i.e. those approaching retirement were more reluctant to save for retirement (more than a half of the respondents answered in the negative). Only $4 \%$ of the respondents are already saving. It can result from people's wrong expectations about security ensured by the state upon their retirement. It can be attributed to unawareness of the pension system or its misunderstanding.

Let us consider the second component of retirement literacy of the RF population, namely, use of outside sources to increase savings rates, apart from the funded pillar. In 2013 Institute for Social Analysis and Prognosis (ISAP) conducted a poll on «Attitude of the population of Russia to the new pension scheme and other directions of the pension system reform» [6]. Working-age respondents were asked about sources of income they are going to count on upon retirement. The ISAP final report lists real sources of income of the respondents older than the working age (retirees). The results are given in figure 2 .

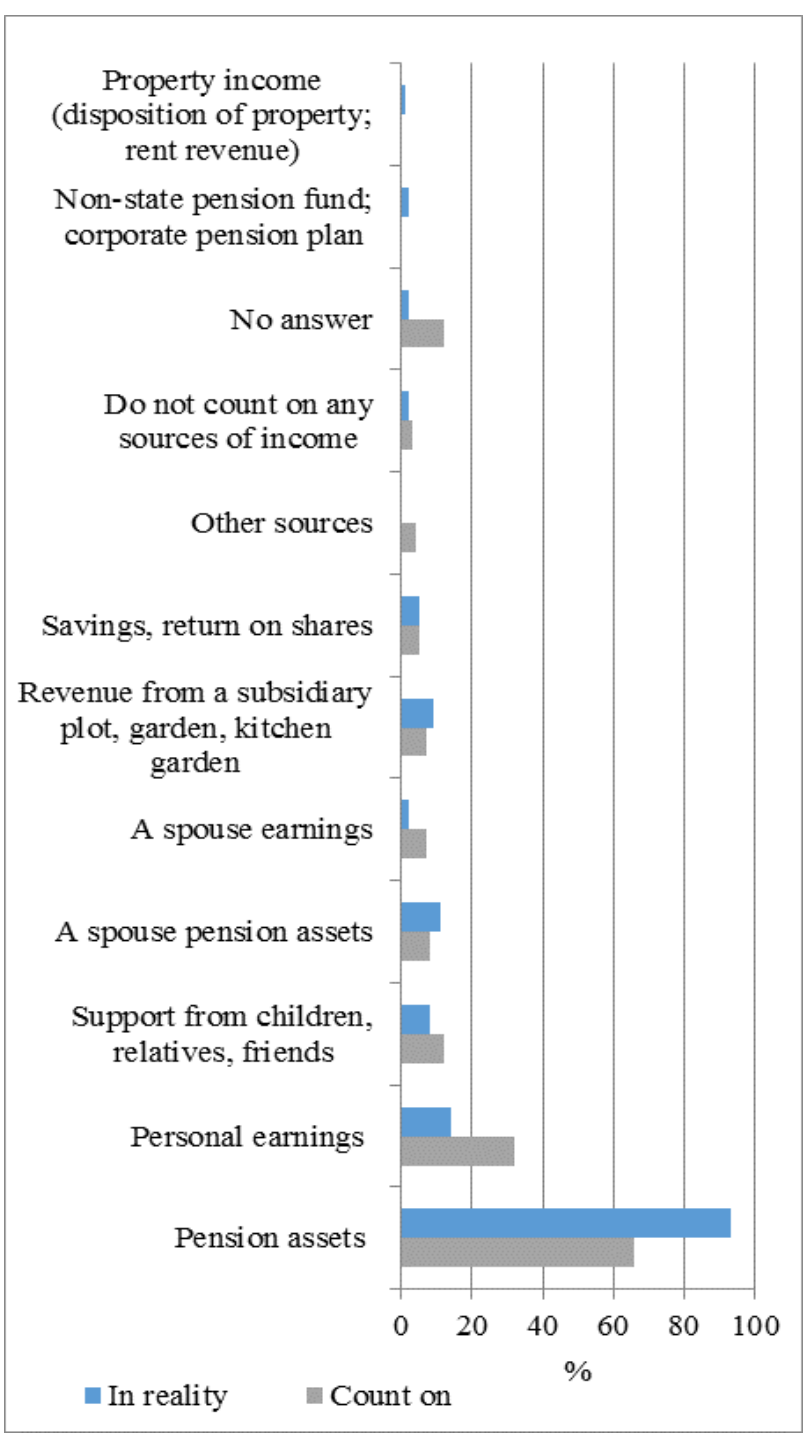

Fig. 2. Results of the poll on sources of income at retirement (2013, ISAP) 
As figure 2 shows, working-age population gives higher priority to other revenues apart from pension. Though, in fact, for $93 \%$ of retirees the primary source of revenue is pension assets. Prospective retirees think that they will be able to continue working in retirement and get additional income to pension $(32 \%$ of respondents). However, only $14 \%$ of the asked indicated the availability of this source of income. In 2015, Public Opinion Foundation conducted another poll on sources of income at retirement. The results changed slightly (figure 3).

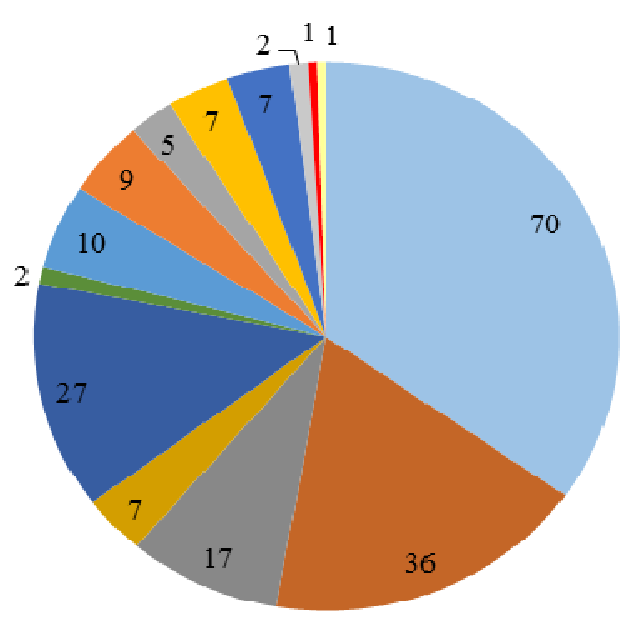

Pension assets

- Personal earnings

m Support from children, relatives, friends

= Revenue from a subsidiary plot, garden, kitchen garden

a Savings, retum on shares

nOther sources

- Don't know /No answer

NPF pension, corporate pension plan

a Property income (disposition of property; rent revenue)

- Revenue from business activity, including farm enterprise

Earnings from equity investment (deposits, bonds)

Revenue from sales (disposition of a house, a car)

- Contract of annuity

Revenue from flat swap (swapping a bigger flat for a smaller one)

Fig. 3. Results of the poll on sources of income at retirement (Public Opinion Foundation, 2015)

In $2015,70 \%$ of working-age population realized the importance of pension assets in the structure of future income at retirement. The respondents also indicated additional revenues, which were not mentioned in 2013.
For instance, $9 \%$ of the respondents indicated non-state fund pension (NPF). A key distinction of the poll conducted in 2015 from the poll of 2013 is a dramatic increase of the share of personal savings in the revenue structure at prospective retirement. It was indicated by $27 \%$ of respondents in 2015 versus $5 \%$ in 2013 . It can be illustrated by answers to the question «How are you planning to save (are already saving) to have an allowance, additional revenue to the state pension upon retirement?» (fig. 4) [4].

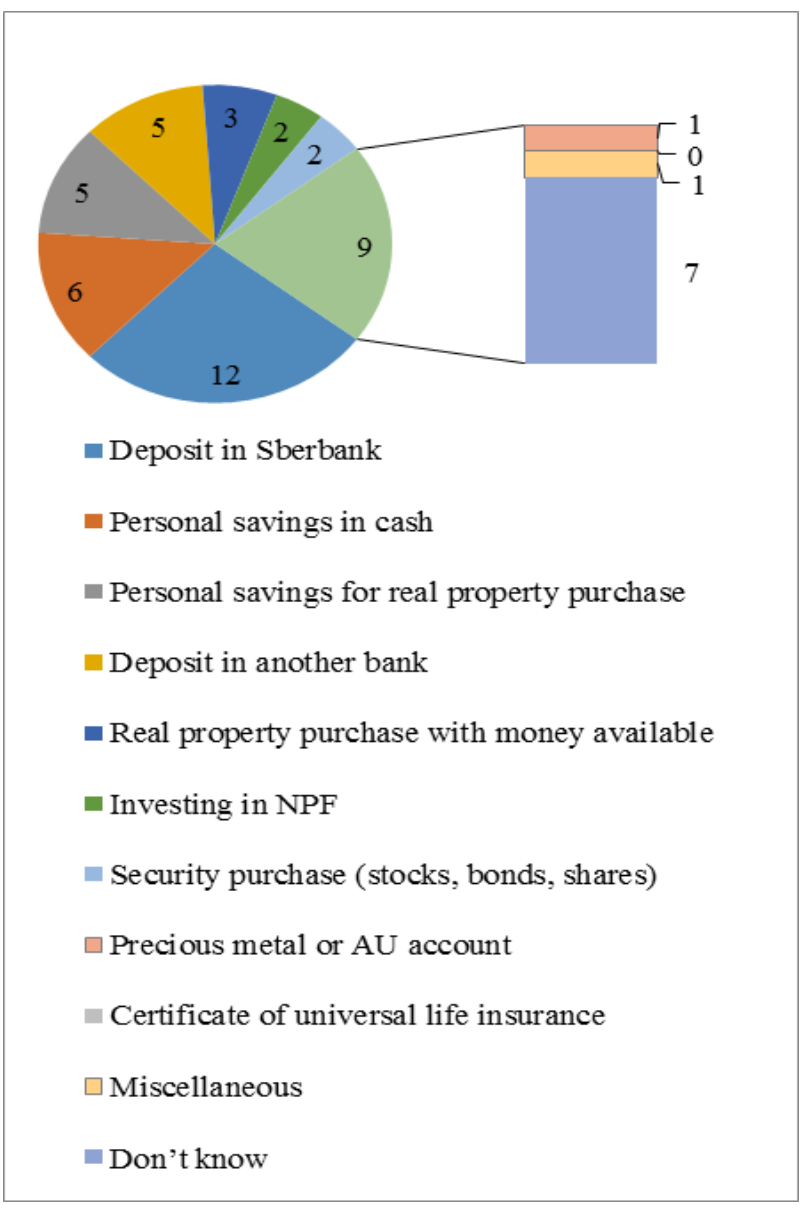

Fig. 4. Results of the poll on types of personal savings for getting extra revenue at retirement (FOM 2015)

Figure 4 also illustrates the third aspect of retirement literacy, namely diversification of the types of personal savings aimed at getting extra revenue at retirement. People aged 47 and younger, who are saving or planning to save to increase pension assets, were polled. The most popular are deposit accounts in Sberbank - $12 \%$, whereas only $5 \%$ of respondents indicated deposits in other banks. Personal savings in cash take the second place in the revenue structure of future pension. It can be attributed to the notorious Russian mistrust to banks and other ways to accumulate assets, including NPF. Only $2 \%$ of respondents indicated participation in NPF voluntary pension programs. However, according to the RF Central Bank data the number of participants of voluntary non-state pension schemes decreased by $9 \%$ from 2013 to 2015 (fig. 5) [5]. 


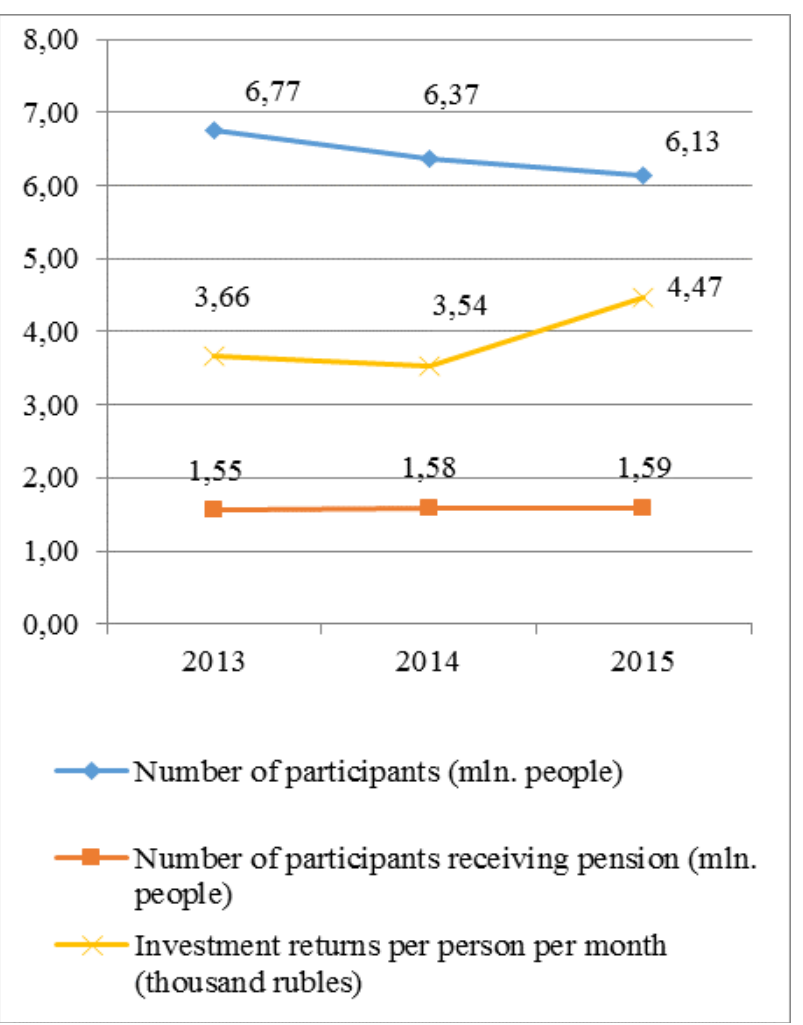

Fig. 5. NPF performance concerning non-state pension provison during 2013-2015 (the RF Central Bank data and authors' calculations)

Every year the number of people choosing non-state pension funds to maintain their funded individual accounts increases [8]. Thus, in 2015 the number of insured people increased by $20 \%$ as compared to 2013 , whereas the number of the able-bodied population decreased by $1 \%$ (Table 1$)$.

Table 1. NPF performance concerning mandatory pension insurance during 2013-2015 (The RF Central Bank data and authors' calculations)

\begin{tabular}{|c|c|c|c|c|}
\hline Indicator & 2013 & 2014 & $2015 *$ & $\begin{array}{c}2015 \\
\text { vs. } \\
2013\end{array}$ \\
\hline $\begin{array}{c}\text { The insured } \\
\text { (thousand of } \\
\text { people) }\end{array}$ & 22186 & 22066 & 26657 & $120 \%$ \\
\hline $\begin{array}{c}\text { Working-age } \\
\text { population }\end{array}$ & 86137 & 85162 & 85415 & $99 \%$ \\
\hline $\begin{array}{c}\text { NPF } \\
\text { participants } \\
\text { versus working- } \\
\text { age people }\end{array}$ & $26 \%$ & $26 \%$ & $31 \%$ & $121 \%$ \\
\hline $\begin{array}{c}\text { The insured } \\
\text { receiving } \\
\text { pension } \\
\text { (people) }\end{array}$ & 324 & 538,48 & 491 & $152 \%$ \\
\hline $\begin{array}{c}\text { Population older } \\
\text { than working- } \\
\text { age }\end{array}$ & 33100 & 33788 & 35163 & $106 \%$ \\
\hline
\end{tabular}

\begin{tabular}{|l|l|l|l|l|}
\hline $\begin{array}{l}\text { Number of } \\
\text { people getting } \\
\text { investment } \\
\text { returns in NPF } \\
\text { versus } \\
\text { population older } \\
\text { than working- } \\
\text { age }\end{array}$ & $1 \%$ & $2 \%$ & $1 \%$ & $143 \%$ \\
\hline $\begin{array}{l}\text { Average from } \\
\text { benefits } \\
\text { compulsory } \\
\text { pension } \\
\text { insurance (rub. } \\
\text { per month) }\end{array}$ & 1081,2 & 614,92 & 755,29 & $70 \%$ \\
\hline
\end{tabular}

*for the period of 9 months

Table 1 shows that in $201531 \%$ of working-age population chose a non-state fund, which is $5 \%$ more than in 2013. It proves prominence of the fourth component of retirement literacy, i.e., people choose a management option to maintain funded individual accounts.

On the one hand, this upward trend is the result of the state activities on developing the NPF system, contributing to activities aimed at averting negative scenarios of the pension system development in future. In other words, a part of the working-age population is already contributing to future pension assets. On the other hand, the increase is slight, as the working-age population follows two behavior models. Some young people opt for remonstrative behavior model, i.e. refuse to participate in the "general retirement scenario». Others choose the social inactivity model, i.e. unspoken approval of the present system: the system cannot be changed; an employer makes some contributions, let things happen as they will. It can be attributed to mistrust to NPF system, resulting from unawareness of clear, step-by-step management of future pension assets. The following factors are to be considered when choosing a certain non-pension fund to manage pension assets: reliability, economic viability, number of customers, NPF affiliation, position on ratings, etc. There are different NPF ratings assessing their reliability, economic viability, savings, opinion ratings, etc. However, trustworthiness of rating agencies can be questioned, because some agencies are concerned about promoting a certain NPF. Consequently, when comparing information from different NPF ratings a prospective retiree may question reliability of the information provided. Moreover, finding objective information and comparing it is time-consuming. Obviously, a solution to the problem can be creating a universal information portal. Electronic government can be used as such to provide analytical information on NPF financial and economic performance, official ratings and other useful information. The information must be provided by specialists on pension assets management working at government agencies. It will enhance confidence of prospective investors and participants of supplementary pension programs in nonstate pension funds and the pension system in general. 


\section{Conclusion}

In the current context working-age population is an important component of the Russian pension system. They not only contribute to the current retirees' pension, but also to their own future pension assets. The analysis of the retirement literacy of the RF working-age population revealed the following tendencies.

Firstly, in the last few years an upward trend of some components of retirement literacy is observed. Currently, only a small part of prospective retirees has necessary information to exercise their rights. About $36 \%$ of the RF working-age population have already made or are nearly ready to make voluntary retirement savings and do not count only on the state support. This indicator can be regarded as satisfactory considering the latest changes in the RF pension system. However, there remains the problem of pension paternalism, implying mistrust of prospective retirees to the state pension system. A paradoxical mutually exclusive principle is observed: we do not trust, though understand that we will have no income at retirement. Thus, to heighten the interest of the RF working-age population in maintaining adequate standard of living in old age, the state can increase the level of retirement literacy. To our mind, the main activity to ensure it can be the so-called «Retirement Literacy Days». Russia has experience of organizing these days, though, only for students and pupils [9].

Secondly, there remain some gaps in such components of retirement literacy of the RF working-age population as information on acquiring extra revenues to increase pension assets, apart from the funded pillar; diversification of types of personal savings aimed at getting extra revenue upon retirement; a choice of a management option for funded individual account (a state pension fund, NPF or a superannuation trustee company).

The analysis revealed the low level of awareness of the Russian working-age population about formation and managing pension savings. Therefore, we conclude that «electronic government» as a universal information portal will allow people analyzing NPF services quickly and easily or obtain free advice from a specialist on financial and economic activity of a non-state fund and choose the most suitable one.

Therefore, the suggested activities will ensure people's deliberate choice on contributing to their retirement assets, and will encourage people to manage their pension savings.

\section{References}

1. Number of retirees and the average established pension in accordance with the type of pension asset and retiree categories (as of January 1). http://www.gks.ru/free_doc/new_site/population/uro v/urov_p2.htm (accessed 11 Mar2016).

2. D. B. Durband, S. L.Britt, Student financial literacy. (Springer: New York, 2012)

3. A. Lusardi, O. S. Mitchell, J Pension Econ Financ. 10(04), 497-508 (2011)
4. O. E. Kuzina, Financial literacy and fiscal jurisdiction: definition, measurement techniques and results of analysis in Russia. Economic issues, 129148 (2015)

5. G. E. Shakhnazaryan, Finances, 5, 18 (2010)

6. Debates on the funded pillar. http://fom.ru/Ekonomika/11690 (accessed 11 Mar2016)

7. Attitude of the Russian population to the new pension scheme and other directions of the pension reform.

http://www.rosmintrud.ru/pensions/razvitie/199/Pen formula_LTC_16_07_2013.pdf (accessed 13 Mar2016)

8. Basic performance indicators of non-state pension funds on compulsory pension insurance. http://www.cbr.ru/finmarkets/?PrtId=sv_coll_invest (accessed 13 Mar2016)

9. E. A. Tarasova, Bulletin of Ulyanovsk state agricultural academy, 4(20), 151-157 (2012) 